vs. "modern" typography.

In a number of instances Mr. Bennett has performed a service that should surely endear him to librarians especially, that of putting valuable material into more readily available form. To mention but one example of this, Edwin Grabhorn's "The Fine Art of Printing" is an essay about paper, ink, type, and also binding that did not deserve the oblivion of the fifty-copy edition in which it was published nearly twenty years ago.

A charming feature of Books and Printing and a technical problem well handled is the setting of the volume in some twenty different type faces. While the majority of the essays are in Janson, others are in faces selected to carry the texts of their own creators or chosen because of an appropriateness to the subject matter. Bennett adds significance to this manner of handling in the final essay, his "On Type Faces for Books," which includes specimens of and notes on each of the types used.

The editor's accomplishment in amassing a rich treasury for the typophile is admirably complimented by designer Joseph Trautwein's accomplishment in providing for it a fine and worthy format, this being attested by the volume's selection as one of the "Top Honor Books" in the Chicago and Midwestern Bookmaking Show and as one of the "Fifty Books of the Year" of the American Institute of Graphic Arts.

Books and Printing deserves high recommendation for library shelves and also for librarians' personal collections.-Edward Connery Lathem, Dartmouth College Library.

\section{The Public Librarian}

The Public Librarian. A Report of the Public Library Inquiry. By Alice I. Bryan. With a Section on the Education of Librarians by Robert D. Leigh. New York: Columbia University Press, 1952. 474p. \$6.00.

Public librarians have had the stimulating experience over the last several years of looking at themselves as others see them. The painstaking accumulation of data by the Public Library Inquiry staff has produced one after another facet of the image that could not otherwise be seen. Some will say that the mirror is so imperfect that the image is almost a caricature. Few will deny the value of all of its parts. The Public Librarian is likely to produce as little conflict of opinion as to its worth, accuracy, or conclusions as any in the series. It is noteworthy that this should be so, as the volume is concerned with the public librarian himself, with the basic questions of personality, training, recruitment, personnel practices and organization, economic status and individual motivation of the individual librarian at all levels. Because the materials of the book are so basic, it can be read with profit and interest by all members of the library profession whether in the public library field or not.

It is fascinating, if not vital, to know that most of the librarians queried would again choose librarianship, that they went into library work because they liked books and people, that male librarians rate highest on the career potential scale as musicians, and that $87 \%$ read for recreation. However, it is surprising and important to learn that only $51 \%$ hold A.B. or B.S. degrees.

Parts III and IV of the Bryan book are the sections most likely to absorb the interest of college and research librarians. Here are handled those knotty and controversial problems of recruitment and training, selection and morale that are common to all types of libraries large and small. We all use the same training institutions and, therefore, are vitally concerned with the way the library schools are doing their job.

Administrators of the smaller libraries might feel that the fundamental criticisms that are implicit in the description of personnel administration do not apply to them. How many of them could, however, take to heart and act upon the suggestions for improved methods of selection, of internal communications, of public and staff relations and record keeping, especially for performance evaluation. The larger libraries which face these problems in a more acute form have moved forward at least haltingly in the direction of meeting them. Multiple and secret classification pay plans, hit or miss training, and the mystified and bewildered staff are not limited to the large, complex institutions.

Several needs fundamental to the profession as a whole emerge for the thoughtful reader as basic. The foremost is certainly improved economic status. Little progress can be made in recruiting for the profession until librarians can look forward to a reasonably adequate 
financial return. Others would be a vigorous and sustained effort to raise both the quality and number of those going into the profession, to make the teaching of librarianship more attractive to promising candidates, to provide job information and candidate information in order to assure better matching of jobs and people, to bring the principles of sound personnel administration into operation in all libraries.

Criticisms of the book limit themselves rather well to criticisms of the method, since the results are interpreted with an honesty, objectivity, fidelity and restraint that are a credit to the author. The sampling method was in this case so intensive, if not extensive, in its operation that a great deal more of expressed opinion lies behind the results than is customary with the sampling method. The safeguard of anonymity in answering the questionnaire should insure a high degree of sincerity in the reply. I for one wonder how many yielded to the temptations of casualness or flippancy behind the veil of anonymity. Not many I think.-Bernard Van Horne, Detroit Public Library.

\section{History of Science}

$A$ Guide to the History of Science; a First Guide for the Study of the History of Science with Introductory Essays on Science and Tradition. By George Alfred Leon Sarton. Waltham, Mass., Chronica Botanica, N.Y., Stechert-Hafner, 1952. xvii, 316p. \$7.50.

The history of science is being studied and consulted more frequently by contemporary historians and social scientists than at any time since the seventeenth century. The cry that the scientist must become socially conscious is matched by the cry that the social scientist must know what science has done in order to understand what it will do. Civilization today affects scientific development and in turn is affected by it. Hence, the librarian whether in a science library or in a general library will find a demand for and a need to know the tools which serve as a key to unlock the storehouse of knowledge concerning the heritage of modern science.

$I$ sis and $O$ siris are by-words in the history of science. To these we can now add Horus, the recommended citing title of Sarton's
"Guide to the History of Science." This new publication will strengthen the arm of every scholar and more particularly every research librarian. It is gratifying to note the increase in the number of guides to the literature of various subjects in the sciences. Chemistry, Mathematics, Physics, Zoology, Entomology, Geology and now the History of Science are well provided with guides.

Sarton's "Guide" is in two parts. The first contains three introductory lectures explaining the purpose and meaning of the history of science. These make fascinating reading. The second part, entitled, "A first guide for the study of the history of science," is a great amplification of the bibliography which was published as an appendix to the author's "Study of the History of Science," Cambridge, 1936. It includes a critical bibliography of works on methodology, and various types of reference tools; a selective list of abstracting and review journals (by Claudius F. Mayer); a directory of societies, national and international devoted to the history of science; critical bibliographies of works on the history of science arranged by country and some fortyone special branches of science; a critical listing of journals and serials concerning the h:story of science (with Claudius F. Mayer); a section on institutes, museums, libraries, and a special section devoted to international congresses. The annotations which are given for most of the publications cited are written in a most interesting and entertaining manner. For example, in speaking of a publication which contains a style manual as an appendix, Dr. Sarton notes that of the principles enumerated, every student "ought to know them as well as he knows how to spell and how to blow his nose."

"A little knowledge is a dangerous thing" and it is always tempting for one on the fringes to seize triumphantly upon and to belabor some minor point which seemingly does not measure up, but Dr. Sarton charmingly disarms the reviewer by his statement on page 71, "Every bibliography contains errors by omission or by commission and at best it is bound to be vitiated by an irreducible minimum of accidental arbitrariness." I cannot refrain, however, from pointing out that the citing title "Horus" which appears only at the head of the title page is bound to cause some bibliographic confusion. Neither the publish- 